\title{
Correlation of Adenosine Deaminase Activity with Cell Surface Markers in Acute Lymphoblastic Leukemia
}

\author{
John F. Smyth, David G. Poplack, Betty J. Holiman, Brigid G. Leventhal, \\ and Geraldine Yarbro, Pediatric Oncology Branch, National Cancer Institute, \\ Bethesda, Maryland 20014
}

A B S T R A C T Adenosine deaminase (ADA) activity has been measured in the lymphoblasts of 23 untreated patients with acute lymphoblastic leukemia and related to the presence or absence of immunologic cell surface markers. The mean ADA activity in the acute lymphoblastic leukemia population as a whole was increased fourfold over that in normal lymphocytes. 9 of the 23 patients were classified as thymus-derived (T-) cell acute lymphoblastic leukemia on the basis of erythrocyte rosette positivity; the remaining 14 patients had null-cell leukemia.

The mean ADA activity (ADA U/mg protein) of T-cell lymphoblasts (102 U) was 3 times higher than the mean of null lymphoblasts $(30 \mathrm{U})$. This difference is statistically significant $(P<0.02)$. Measurement of ADA activity offers a biochemical method of distinguishing between immunological subtypes of lymphoblasts which may be of prognostic and therapeutic value.

\section{INTRODUCTION}

Acute lymphoblastic leukemia (ALL) ${ }^{1}$ is no longer thought to represent a single disease entity, and currently there is considerable attention focused on the immunological and biochemical subclassification of this group of diseases. Immunological classification based on the identification of bone marrow-derived (B-) and thymus-derived (T-) cell sub-populations has shown that lymphoblasts from $70-80 \%$ of patients with ALL lack both B- and T-cell markers (null cells), whereas $20-30 \%$ can be shown to be of T-cell origin, and only $2 \%$ of all cases are of B-cell type (1). Recently, the activity of the enzyme adenosine deaminase (ADA) has been shown to have specific importance for the metab-

\footnotetext{
Received for publication 13 June 1977 and in revised form 10 May 1978.

${ }^{1}$ Abbreviations used in this paper: ADA, adenosine deaminase; ALL, acute lymphoblastic leukemia; E, erythrocyte; EAC, erythrocyte antibody complement.
}

olism of lymphocytes (2). Tissue distribution studies show that ADA is usually present in all the tissues of the body with the highest activity in lymphocytes (3) and thymocytes (4). Furthermore, congenital absence of this enzyme, which arises as an inborn error of metabolism, results in the syndrome of severe combined immunodeficiency (5-8). ADA activity has been found to be subnormal in the lymphocytes of patients with chronic lymphocytic leukemia $(9,10,11)$ a disease characterized by immunologic impairment and an abnormal proliferation of B cells (12). We previously demonstrated that the ADA activity of acute leukemia lymphoblasts is greatly increased in comparison with normal lymphocyte levels (3), and this has subsequently been confirmed by other studies $(4,11)$. The considerable variation in absolute ADA activity among ALL patients noted previously, and the known immunological heterogeneity of ALL, prompted us to study leukemic lymphoblasts to determine whether a correlation exists between ADA activity and immunological subclasses of ALL.

\section{METHODS}

Patient population. Newly diagnosed patients with ALL cared for on the Pediatric Oncology Branch of the National Cancer Institute were studied. The diagnosis of ALL was based on classical clinically accepted criteria (13). The patients ranged from 1 to $30 \mathrm{yr}$ of age; none had received treatment before the collection of their lymphoblasts.

Cell collection. Lymphoblasts were collected from peripheral blood by leukapheresis at the time of the patient's initial admission. The cells were harvested by dextran (Pharmacia Fine Chemicals Inc., Piscataway, N. J.) sedimentation and stored in Teflon (Du Pont, E. I. de Nemours \& Co., Inc., Wilmington, Del.) bags in a viable state in liquid nitrogen with $10 \%$ dimethylsulfoxide at $-140^{\circ} \mathrm{C}$. On the day of the tests, cells were thawed rapidly, washed twice, and placed on a Ficoll-Hypaque density gradient that consisted of $9 \%$ Ficoll (Pharmacia Fine Chemicals Inc., Piscataway, N. J.) and $34 \%$ Hypaque (Winthrop Laboratories, New York). This technique allowed nonviable cells to pass through the gradient. $95 \%$ of the remaining cell suspension was viable as assessed by trypan blue exclusion. 
Preparation of cell extracts. The separated lymphoblasts were resuspended at $4^{\circ} \mathrm{C}$ in a $0.15-\mathrm{M}$ phosphate buffer $(\mathrm{pH}$ 7.1 ), and the cell concentration adjusted to $0.5-1.0 \times 10^{7} / \mathrm{ml}$ before disrupting a 3-ml vol of cells by sonication (45 $\mathrm{s}$ at 40 kHz, Biosonic, Bronwill Scientific, Rochester, N. Y.). The suspension was then centrifuged at $800 \mathrm{~g}$ for $10 \mathrm{~min}$, and the supernate used for the enzyme assay.

Adenosine deaminase assay. ADA activity was assayed by a modification of Kalckar's technique (14), on a Gilford, 2,400-2 spectrophotometer (Gilford Instruments Company, Oberlin, Ohio) at $30^{\circ} \mathrm{C}$. The sample cuvette contained $0.3 \mathrm{ml}$ adenosine $(2 \mathrm{mM})$ and $2.2 \mathrm{ml} 0.15-\mathrm{M}$ phosphate buffer $(\mathrm{pH} 7.1)$. The reaction was started by the addition of $0.5-\mathrm{ml}$ cell extract, and followed by recording the initial decrease in OD at $265 \mathrm{~nm}$, which was linear for at least $5 \mathrm{~min}$. Protein estimations of the same cell extract were performed by the technique of Lowry et al. (15). $1 \mathrm{U}$ of ADA activity is defined as the amount of enzyme activity which produces a decrease in OD of 0.010 / min under the conditions described $(3,16)$.

$B$ - and T-cell markers. Erythrocyte- (E) rosette formation was measured by a previously described method with neuraminidase pretreated sheep erythrocytes (17). Erythrocyte antibody complement (EAC) rosettes were measured with a commercially available reagent (EAC, Cordis Corp., Miami, Fla.) by a previously reported method (18). At the end of these procedures, cells were spun in a cytocentrifuge and Giemsa stained. The morphology of the rosetteforming cells was determined by microscopic examination and the percentage of lymphoblasts forming $\mathrm{E}$ and EAC rosettes counted. In all patients with T-cell ALL, $>10 \%$ of the lymphoblasts formed E rosettes, while $0-1 \%$ of the lymphoblasts from individuals considered to have null-cell disease formed $\mathrm{E}$ rosettes. Thus, delineation of patients into these two categories is consistent with previously described criteria for the immunological subclassification of patients with ALL (19).

\section{RESULTS}

The results of measuring ADA activity in the lymphoblasts of 23 ALL patients, and the lymphocytes from 10 controls are illustrated in Fig. 1. For the leukemic population, the mean ADA activity was $58 \mathrm{ADA} \mathrm{U} / \mathrm{mg}$ protein (range: 7.5-161.5 U) compared with a mean of $14 \mathrm{U}$ in control lymphocytes (range: 6.4-35.7 U). For this entire group of ALL patients, the mean ADA activity was 4 times greater than in control lymphocytes.

Lymphoblasts showed E-positive rosettes in 9 of the 23 patients. These individuals were classified as $\mathrm{T}$ cell ALL. In all patients with T-cell disease, $>10 \%$ of the lymphoblasts were E-rosette positive. In the other 14 patients, $<1 \%$ of the lymphoblasts were E-rosette positive. These patients were classified as null-cell ALL. There were no B-cell ALL patients in this study.

Fig. 1 also shows the ADA activity of individual patients grouped on the basis of cell surface markers. ADA activity in the T-cell ALL patients ranged from 32.0 to 161.5 ADA U/mg protein. The mean ADA activity was 3 times higher in $T$ lymphoblasts (102 U) than in null lymphoblasts $(30 \mathrm{U})$. This difference, when analyzed by the Wilcoxon rank-sum test, is highly significant $(P<0.02)$.

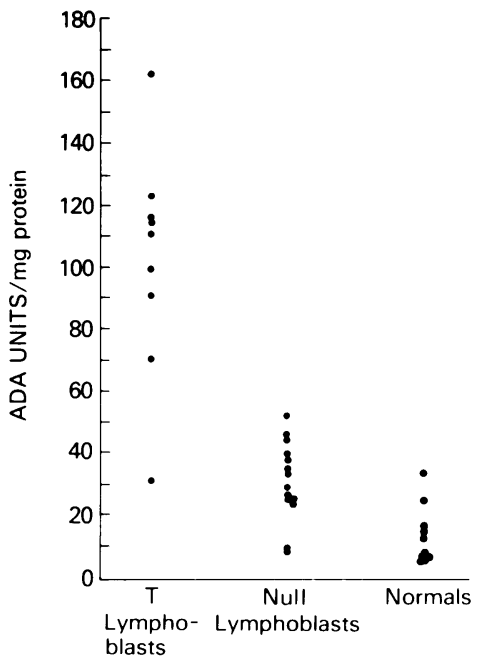

FIGURE 1 Adenosine deaminase (ADA) activity (ADA U/mg protein) in the lymphoblasts of 23 patients with ALL compared with the lymphocytes of 10 normal controls. Patients are grouped according to cell surface immunological markers, determined by standard E- and EAC-rosetting techniques. ADA was assayed spectrophotometrically in the supernatant fraction of sonicated cells. $1 \mathrm{U}$ of ADA is defined as the amount of enzyme activity which produced a decrease in OD of $0.010 /$ min under the described conditions.

\section{DISCUSSION}

In this study we have confirmed that ADA activity is elevated in acute leukemia lymphoblasts and that there is considerable variation in enzyme activity among different patients. Immunological and biochemical subclassification of these patients on the basis of their cell surface markers and ADA levels demonstrated a highly significant positive correlation between T-cell ALL and high ADA activity.

With current therapy, approximately $50 \%$ of ALL patients may expect to survive disease free for $5 \mathrm{yr}$ or more (20). Such encouraging results make it important to establish the prognosis for individual patients at the onset of treatment, particularly if it becomes possible to identify patients in a poor-prognostic category for whom different and more intensive therapy may be indicated (1). It has been shown that $20-25 \%$ of ALL patients have T-cell surface markers, and that these patients respond less well to therapy than the larger proportion of patients with null-cell ALL (21). Because the presence of high levels of ADA correlates with T-cell leukemia, determination of ADA activity in the lymphoblast cells of newly diagnosed ALL patients offers a simple and rapid technique to identify patients with a less favorable prognosis.

Although the reasons for the high ADA levels in Tcell lymphoblasts are not known, this phenomenon may be therapeutically exploitable. Recently, it has been 
shown that inhibition of lymphocyte ADA impairs lymphocyte function in vitro (2), and causes lymphocytotoxicity in vivo (22). The use of such potent inhibitors of ADA as coformycin (2) and 2'-deoxycoformycin (23) may provide a new and specific approach to the therapy of T-cell ALL, a disease which is usually resistant to currently available chemotherapy.

\section{REFERENCES}

1. Editorial. 1976. Prognostic factors in childhood leukemia Br. Med.J. 2: 386-387.

2. Hovi, T., J. F. Smyth, A. C. Allison, and S. C. Williams. 1976. Role of adenosine deaminase in lymphocyte proliferation. Clin. Exp. Immunol. 23: 395-403.

3. Smyth, J. F., and K. R. Harrap. 1975. Adenosine deaminase activity in leukemia. $\mathrm{Br}$. J. Cancer. 31: 544-549.

4. Coleman, M. S., and J. J. Hutton. 1975. Terminal deoxynucleotidyl transferase and adenosine deaminase in human lymphoblastoid cell lines. Exp. Cell Res. 94: 440-442.

5. Giblett, E. R., J. E. Anderson, F. Cohen, B. Pollara, and H. J. Meuwissen. 1972. Adenosine deaminase deficiency in two patients with severely impaired cellular immunity. Lancet. II: 1067-1069.

6. Dissing, J., and B. Knudsen. 1972. Adenosine deaminase deficiency and combined immunodeficiency syndrome. Lancet. II: 1316.

7. Parkman, R. G., F. W. Gelfand, F. Rosen, A. Sanderson, and R. Hirschorn. 1975. Severe combined immunodeficiency and adenosine deaminase deficiency. N. Engl.J. Med. 292: 714-719.

8. Meuwissen, H. J., B. Pollara, and R. J. Pickering. 1975. Combined immunodeficiency disease associated with adenosine deaminase deficiency. J. Pediatr. 86: 169-181.

9. Scholar, E. M., and P. Calabresi. 1973. Identification of the enzymatic pathway of nucleotide metabolism in human lymphocytes and leukemia cells. Cancer Res. 33: 94-103.

10. Tung, R., R. Silber, F. Quagliata, M. Conklyn, J. Gottesman, and R. Hirschorn. 1976. Adenosine deaminase activ- ity in chronic lymphocytic leukemia. J. Clin. Invest. 57: 756-761.

11. Meier, J., M. S. Coleman, and J. J. Hutton. 1976. Adenosine deaminase activity in peripheral blood cells of patients with haematological malignancies. Br.J. Cancer. 33: 312319.

12. Pincus, S. C., C. Bianco, and V. Nussenzweig. 1972. Increased proportion of complement-receptor lymphocytes on the peripheral blood of patients with chronic lymphocytic leukemia. Blood. 40: 303-309.

13. Wintrobe, M. M., G. R. Lee, D. R. Boggs, T. C. Bithell, J. W. Athens, and J. Foerster. 1974. The acute leukemias. In Clinical Hematology. Lea and Febiger, Philadelphia, Pa. 7th edition. 1472-1534.

14. Kalckar, H. M. 1947. Differential spectrophotometry of purine compounds by means of specific enzymes. J. Biol. Chem. 167: 427-443.

15. Lowry, O. H., N. J. Rosebrough, A. L. Farr, and R. J. Randall. 1951. Protein measurement with the Folin phenol reagent. J. Biol. Chem. 193: 265-275.

16. Hall, J. G. 1963. Adenosine deaminase activity in lymphoid cells during antibody production. Aust.J. Exp. Biol. Med. Sci. 41: 93-98.

17. Weiner, M. S., C. Bianco, and V. Nussenzweig. 1973. Enhanced binding of neuraminidase-treated sheep erythrocytes to human T lymphocytes. Blood. 42: 939-946.

18. Bowles, C. A., G. T. White, and B. Lucas. 1975. Rosette formation by canine peripheral blood lymphocytes. J. Immunol. 114: 399-402.

19. Humphrey, G. B., and S. Lankford. 1976. Acute leukemia: the use of surface markers in classification. Sem. Oncol. 3: 243-253.

20. Simone, J. V., J. V. Rhomes, H. Aur, O. Hustu, M. Verzosa, and D. Pinkel. 1975. Combined modality therapy of acute lymphocytic leukemia. Cancer (Phila.). 35: 25-35.

21. Tsukimoto, I., K. Y. Wong, and B. C. Lampkin. 1976. Surface markers and prognostic factors in acute lymphoblastic leukemia. N. Engl. J. Med. 294: 245-248.

22. Smyth, J. F., R. C. Young, and D. M. Young. 1978. In vivo toxicity to lymphoid tissue by 2-deoxycoformycin. Cancer Chemother. Pharmacol. 1: 49-51.

23. Woo, P. W. K., H. W. Dion, S. M. Lange, L. T. Dahl, and L. Durham. 1974. Novel adenosine and ara-A deaminase inhibitor. J. Heterocycl. Chem. 11: 641-643. 